\title{
THE INSTITUTIONAL ORGANIZATIONAL THEORY AS A NEW RESEARCH FRAMEWORK FOR UNDERSTANDING CONTEMPORARY ORGANIZATIONS
}

\author{
Nebojša Janićijević \\ University of Belgrade, Faculty of Economics, Serbia \\ \jnebojsa@eunet.rs
}

UDC
378
Review paper

Received:

10.05.2014

Accepted:

10.10.2014

\begin{abstract}
This paper presents basic postulates of the institutional, organizational theory as a new research framework for understanding contemporary organizations structuring and functioning. More and more structures in modern societies are being institutionalized due to changes in technical, social, and political spheres. Organizations in institutionalized sectors do not prove their legitimacy by their rationality and effectiveness, but by implementation of the current institutional pattern. Institutional pattern has its regulatory, normative, and cultural-cognitive components, and it is imposed on organizations within a sector by means of coercive, normative, and mimetic mechanisms. The consequence of implementing of a uniform institutional pattern in the structuring and functioning of all organizations within a sector is organizational isomorphism. The described elements of the institutional, organizational theory are applied in the analysis of structuring and functioning of universities and faculties in the higher education sector in Europe and Serbia. It is shown how the Bologna Higher Education Model, as a typical institutional pattern, impacts structuring and functioning of all universities and faculties in the European higher education area, thereby implicating their organizational isomorphism.
\end{abstract}

Keywords: institution, theory, organization, higher education, university

\section{Introduction}

We are witnessing that in more and more economic sectors and sectors of society, both in the world as well as in Serbia, organizations increasingly resemble one another. This phenomenon, in the literature called organizational isomorphism (DiMaggio and Powell, 1983), is caused by the fact that organizations within one economic sector or sector of society implement 
identical or nearly identical both organizational structure and processes. In other words, organizations resemble one another since they implement the same structuring and business operations models (Scott, 1987). Thus, all the universities and faculties in the higher education sector in Europe, and in Serbia as well, implement the same studying regime and structure, teaching and student evaluation processes, quality assurance mechanism, organizational structure, etc. All the railway companies in Europe, Železnice Srbije (Serbian Railways) including, implement the same structural model based on separation of the infrastructure from the transportation capacity. This model is increasingly being implemented in other infrastructure sectors, so more and more power companies as well as telecommunication companies implement the model in which infrastructure is separated from the traffic circulating on the said infrastructure. Banks, as well as television companies, more and more resemble one another. Every company wishing to demonstrate that it is applying quality management does that in only one way - by implementing ISO standards. This implies that all those companies have the same organization and implement similar quality management procedures. Consulting companies, auditing firms, and also advertising companies show surprising resemblance in their organizational structure and business model.

Organizational isomorphism is one of the symptoms of social changes leading to obsolesce of the existing and emerging of new organizational theories. It cannot be explained by theories of organization dominating the second half of the twentieth century. The predominant contingency theory of organization explains that organizing is a rational process in which organization management, having in mind the context of the organization and the relevant factors impacting the organization, selects the most rational organizational model that will ensure maximum economic performance (Mintzberg, 1979). There is no ideal organization, and there is no "one best way" of organizing, but an organization depends on the situation in which company finds itself (Jones, 2001). Due to this, according to the predominant contingency theory, organizations should be idiosyncratic, and not isomorphic. Therefore, the contingency theory cannot explain isomorphism emergence and it provides no answers to the question: Why is it that in some economic sectors and sectors of society organizations implement completely identical structuring and functioning models? How is it that an ideal model of organization, the one best way, nevertheless exists even though the contingency theory claims that it in fact does not?

However, the institutional theory of organization does provide the answer to this question. It represents a theoretical framework which enables the understanding of organizational isomorphism and organizational structuring of contemporary organizations in many sectors of modern society. This theory has the potential to explain isomorphism because it is different from the 
contingency theory of organization with respect to three major points (Scott, 2001). First, in institutional, organizational theory, organizing process is not a rational decision made by organization management, and organizing is done through accepting and implementing an already shaped institutional pattern of structure and functioning. Second, organization structuring and functioning model did not emerge within the organization itself, but outside of it, in an institutional environment, and it is in effect in all organizations within one sector. Third, the institutional pattern of organization structuring and functioning in a sector is not necessarily technically rationally and economically effective, which is the assumption of contingency theory of organization. Therefore, the basic postulate of institutional theory of organization is that structuring and functioning of all the organizations within a sector is done according to the institutionalized pattern created in the said sector and imposed on all the organizations within it (Scott, 1987). If structuring and functioning of organizations in one sector are understood in this way, then organizational isomorphism is the natural and logical consequence. Organizations resemble one another simply because they implement the same structuring and functioning pattern which is created at the sector level, institutionalized, and, as such, imposed on all organizations within the said sector. There are an increasing number of economic sectors and sectors of society in which the process of structuring and functioning of organizations is no longer conducted according to the contingency theory postulates, but in the way it is described in the institutional organizational theory. This is the reason why this theory is becoming more and more relevant today as a research framework for the understanding of contemporary organizations.

The aim of this paper is to present the basic postulates of institutional theory of organization, as well as to demonstrate, through the example of higher education structuring in Serbia, how this theory may be used for understanding of the structure and functioning of modern organizations. The paper is structured as follows. First, we will explain the basic elements of institutional, organizational theory, such as: the nature of institutions, the way institutions emerge, institution types, the mechanism of imposing of institutions, and the reactions of organizations to institutions. Afterwards, the structuring and functioning of universities and faculties in the higher education sector in Serbia will be explained by applying the institutional organizational theory.

\section{Structuring and Functioning of Organizations in Institutionalized Sectors}

Institutional theory primarily developed within sociology and political sciences with pioneering institutionalists such as Spencer, Sumner, Cooley, Hughes, Marx, Weber, Durkheim and Parsons (Scott, 2001). In the 1940s, the institutional theory entered the field of organization with the appearance of the 
first organizational institutionalists: Selznick, March and Simon. In the second half of the twentieth century, neo-institutionalists emerged in organizational theory. The key concepts of organizational neo-institutionalism were set by Meyer and Rowan (1977), Zucker (1977), DiMaggio and Powell (1983), Scott (1987, 1991, 2001), Oliver (1991, 1992), Edelman (1992), Greenwood and Hinings with their associates (1988, 1996, 2008), Kostova (1999), Thornton (2002), Pedersen and Dobbin (1997, 2006). This stream of institutionalism in organizational theory remains alive and active, producing a great number of works as well as new concepts and models.

The central argument of the organizational, institutional theory is that the structuring and functioning of organization in an economic sector or a sector of society is determined by institutions (Meyer, Rowan, 1977). Institutions in every sector prescribe the institutional organizing and functioning pattern and impose it on all organizations within the sector. The basic assumption that underlies this argument is that organizations prove their legitimacy in society by implementing institutionally imposed pattern, and not by technical or economic efficiency. Each organization as a social actor must prove that it is legitimate in order to gain the right and the opportunity to engage social resources. Legitimacy is a generalized perception or assumption that the actions of one entity are desirable, suitable, and adequate within the framework of specific social values, norms, beliefs and definitions (Scott, 2001). In the industrial society era, organizations had been proving their legitimacy by applying technical and economic principles of rationality and efficiency, and the market mechanism was actually the authority determining which organizations succeeded and which failed to prove their legitimacy. However, in postindustrial, modern society there are more and more sectors in which a specific pattern of structure and processes in organizations is institutionalized as the only rational, desirable, and beneficial for the society. Organizations in those sectors no longer prove their legitimacy by following technical and economic demands of rationality and efficiency, but by applying the institutionalized pattern of structuring and functioning. To the extent in which a sector is institutionalized, the market is suspended as a regulatory mechanism and arbiter in determining legitimacy of organizations within the sector, and the institutions of that sector take over this role instead. The irony is that the institutionalized pattern of business operations, which is imposed to the organizations in one sector needn't be neither rational nor effective way of social resources spending at all. Just remember the model of organizing of selfmanaging enterprises as work organizations in former Yugoslavia. This institutionalized pattern of organizing enterprises was proven to be inefficient and irrational way social resources spending, but it still had to be applied. The way in which institutions and institutionalized rules of structuring and functioning of organizations emerge provides no guarantees that they will be rational and efficient, either technically or economically. Institutions may, but 
they do not have to, provide rationality and efficiency in social resources spending by means of creating and imposing the structuring and functioning pattern of organizations.

In order to explore the impact of institutionalization on contemporary organizations, the following issues must be explained: 1 . What is the nature of the institutions and institutionalized patterns imposed by them and how do they emerge?; 2. Are all the sectors exposed to the institutionalization in the same extent, or are some exposed more and some less, and why?; 3. What types of institutions within the sector are there?; 4 . What is the mechanism of impact of these institutions, that is, how do they impact the structuring and functioning of organizations?; 5. How do organizations react to the institutional pressure? The answers to these questions will be provided in the remaining text, and they will in turn be applied to higher education sector in Serbia.

\section{Source and Nature of Institutions in Modern Societies}

According to Weber, people in the era of capitalism are prisoners of the iron cage of rationalism, which is best achieved through bureaucratic organization of firms and the society as a whole (DiMaggio, Powell,1983). The rationalism of organizations emerges from three factors: market competition between organizations, competition between the states, and the wishes of the rulers of the states to control the citizens. The most important source is still the competition between the organizations present on the market, which implies the need for technical rationality and economic efficiency. The organization which provides the most rational social resources spending will win the market competition, and it will be the organization which rationalizes and formalizes its structure and functioning to the largest extent. According to Weber, the most rational organization is in fact bureaucracy; hence it is the symbol of capitalism. However, in modern postindustrial societies, the prime source of rationalization is no longer market competition, but the state and the profession. The main reason for this is the more and more intense striving of power elites in those societies to control the citizens. The development of modern technology, which makes objective evaluation of modern organizations' input and output difficult, also contributes to institutionalization. In such societies, the market is suspended as a mechanism of social resources allocation, and institutions slowly take over that role instead of it. Organizations must still meet the criteria of rationality, but the rationality of an organization is no longer proved on the market by observation of technical and economic criteria, but by meeting the criteria defined by institutions, often through the actions of the state and professions.

According to Scott (1987), institutionalization is basically the process of creating and stabilizing of the meaning of reality, and institutions are stable systems of social beliefs and rules that govern the defining of practices in many 
functional spheres of life. Berger and Luckmann (1967) had long ago pointed out the importance of the social construction of reality. They asserted that behavior of social actors is determined by their interpretation of reality that surrounds them, and that they construct that reality in social interactions with other social actors. This is the reason why a socially constructed reality can be differed from an "objective" reality, if such reality exists at all. For the understanding of social life, not the objective reality as such, but its interpretation by the actors is of utmost importance. Social actors shape their actions not based on the objective reality, but based on their own interpretation of that reality. "Situation marked by people as real, becomes real by its consequences." This is why social order is a result of shared understandings constructed by the members of a community through their interactions. Social order or reality emerges when an individual or a group takes action, interprets this action and then shares it with others in order to categorize the actions of people and to be able to react to them in a similar manner. This is actually the process of institutionalization: repeating certain types of actions (behavior) and giving those actions a specific meaning in order to be able to understand them and respond to them.

The process of institutionalization proceeds in three phases (Scott, 2001): 1 . Externalization - one, together with other members of social community, group or organization, takes the actions and interactions that produce symbols which carry meaning shared by all participants in the interactions; 2 . Objectification all members of one community interpret those actions and interactions together, as if they are part of some objective reality outside of themselves, and the symbolic structures produced in those actions and interactions begin to be treated as objective, as something that is "out there", separated from the individual who participated in their creation, as a reality which an individual experiences together with other people; 3 . Internalization - members of a community implement the interpretations of the objective world (i.e. the actions of the members of the community) in their consciousness (retrojecting) through the process of socialization. These three phases result in people actually creating their world, which they then experience as something outside of themselves, objectively. Institutionalization is a social process in which people accept social construction of reality, i.e. in which people through interactions and interpretations establish and accept common meanings which they attribute to their own actions and actions of others. This is how the reality becomes taken for granted; it becomes allegedly independent of the actions of an individual (or at least that is what one claims) and shows "how things are done here" or "how things should be done". Organizations in an institutionalized world actually react to the environment they themselves create (DiMaggio, Powell, 1983). In this way, the criteria of their behavior are not independent from themselves any more, which implies that the institutionalized pattern of social actors' behavior can, but it does not necessarily have to, be technically rational and economically 
efficient way of social resources use. Having in mind that the process of institutionalization is basically subjective, it cannot be predicted what kind of rules of social actors' behavior will be institutionalized and imposed on these actors, and it can be even less guaranteed that they would also be technically and economically rational.

In the process of social constructing of the reality, actions of social actors are being „infused with value“ in order to be imposed as such to other social actors (DiMaggio, Powell, 1983). Value of a certain pattern of behavior does not at all need to originate from the fact that this pattern is technically rational or economically efficient way of social resources spending. The institutionalized pattern of behavior is valuable because it is generally accepted and because it complies with shared understandings of reality, and not because it is objectively proven to be rational. Additionally, it can be rational and efficient, but only in specific contexts and in some organizations, while in different contexts or other organizations it may be irrational and inefficient. When a certain rule, structure or process is being institutionalized, it is marked by social actors as valuable and legitimate, and therefore all other actors within a sector, in order to prove their legitimacy and value, must accept and implement it. Thus, for example, some technical innovation done by one organization motivated by technical efficiency (such as, for example, Total Quality Management - TQM) is being „infused with value“, which exceeds technical aspect of this innovation (Casile, Davis-Blake, 2002). In time, acceptance of this innovation becomes obligatory to all other organizations which in that way prove the legitimacy of their existence. There is a break even point when technical innovation becomes institutionalized and rationalized myth which must be accepted in order to prove legitimacy. This innovation does not have to be applicable or successful in other organizations, but it nevertheless must be implemented. The consequence is that the early acceptors of TQM accepted this model on the basis of technical arguments (better quality), while late acceptors did so on the basis of institutional arguments, that is, to provide legitimacy for themselves.

The institutionalized patterns of structuring and functioning of organizations often have the form of contemporary myths (Meyer, Rowan, 1977). They have two characteristics: first, they are highly rationalized and impersonal, and they determine the purpose of behavior as well as the methods of behavior; second, they are institutionalized in such a way that they are beyond the influence of individual organizations. Institutionalized organizational behavior includes stable, repetitive, and permanent activities, which have meaning and values that surpass their technical goals. Institutionalized practices are seen as natural, only possible, and therefore legitimate (Oliver, 1992). Organizations are bound to accept and implement institutionalized patterns of behavior in order to prove their legitimacy, even when they are aware that those are just myths. In order to 
obtain legitimacy, organizations must conform to institutionalized patterns of structuring and functioning which are taken for granted. The organizational action will be rational and efficient only to the extent in which that pattern is rational and efficient. But, we have seen that there is nothing in the process of institutionalization that would guarantee rationality and effectiveness of the output of that process: pattern of behavior of the social actors.

It is interesting that the replacement of technical and economical criteria of efficiency by the application of institutionalized myths in defining of the successfulness of organizations suits the organizations themselves. This replacement significantly decreases the degree of uncertainty which the organizations are faced with. Uncertainty is one of the greatest "enemies" of every organization, since they prefer stability and certainty. If the legitimacy and successfulness of organizations are measured based on technical efficiency, organization is facing a significant uncertainty. Its outputs must meet the everchanging objective technical and economic standards. However, if its successfulness is measured based on the fact to what extent it has implemented the institutionalized pattern of structuring and functioning, the organization does not at all depend on its output, but on its skill to recognize and conform to institutionalized rules of the sector in which it operates. Whether some company will be a legitimate user of social resources does not depend on its outputs, but on whether or not it applies the imposed model of structuring and business practice. A faculty will be legitimate if it follows the existing model of university education regardless of average duration of studying, students' average grade or their quantum of knowledge. In institutionalized sectors, the only source of uncertainty for organizations is the (lack of) knowledge about the institutionalized structure and functioning model, while technical sources of uncertainty are neutralized.

\section{The Level of Institutionalization in Different Sectors}

Institutionalization is a process which proceeds at the level of sectors, but it does not proceed equally in all the sectors. Some sectors are less and some are more exposed to the process of institutionalization. Institutionalists sometimes refer to sectors as "organizational field", with the definition that sectors are "organizations that make a clear and identifiable entity observed from the aspect of institutional life" (Ashworth et al., 2007). Organizational field is also defined as a set of organizations sharing a model of behavior because they share the same values and norms (Hinings et al., 2004). In order for a sector or a field to be created, structuring must take place (DiMaggio, Powell, 1983). It is a process in which organizations mutually interconnect, enter interactions and then create inter-organizational structures and information which all organizations in the field share among each other and thereby they create the awareness that they are inside the field. 
There are two factors determining the extent of exposure of a sector or the organizational field to the process of institutionalization: 1 . The extent in which the output of organizations can be measured, evaluated and standardized; 2 . The extent in which the organizations in a sector are able to control the flow of resources, i.e. their inputs (Frumkin, Galaskiewicz, 2004). The larger the degree of output standardization of the organizations in the field and the more they may be measured and quantified, the organizations will be less exposed to the pressure of institutionalization and they will more acknowledge the criteria of technical and economic efficiency in their work. And vice versa, the less the possibility of standardization and objective determining of quality and quantity of outputs, the organizations will be more exposed to the pressure of accepting the institutionalized rules in the field. On the other hand, the less the possibility of organizations to influence the engagement of social resources, the more the organizations will be exposed to the pressure of institutionalization.

For different reasons, development of modern societies follows the direction of increasing the number of sectors in which the conditions of institutionalization are met, so the modernization implies wider institutionalization as well. Contemporary countries and their political elites, aspiring to expand their control over citizens, strive to institutionalize the ever larger number of the spheres of life. On the other hand, technological development has provided an ever larger degree of freedom to organizations, so they become less dependent on technology and less forced to comply with technical rules of structuring, and thus they are more exposed to institutionalization. The consequence is that the number of sectors in which institutions suspend the market and technical rationality is increasing, and in those sectors the number of institutions which the sectors must conform to is increasing as well as the number of rationalized rules they prescribe.

\section{Regulative, Normative and Cultural-Cognitive Institutions}

Institutions are "socially constructed systems of roles or programs that produce routines" (Jepperson, 1991, p 146). Institutions consist of culturalcognitive, regulative and normative elements which together with associated actions and resources provide stability and meaning to social life (Scott, 2001). Institutions are by definition stable, but they can change both incrementally and radically.

The results of the institutionalization process are three types of institutions, which impose the institutionalized rules in different ways. The three types of institutions are: regulative, normative and cultural-cognitive (Scott, 2001). Their characteristics as well as the principles of operation may be seen in the following table: 
Table 1 Three Types of Institutions

\begin{tabular}{|l|c|l|c||}
\hline Institution & Regulative & Normative & Cultural-cognitive \\
\hline $\begin{array}{l}\text { Basis of } \\
\text { consideration }\end{array}$ & $\begin{array}{c}\text { Properness, } \\
\text { convenience }\end{array}$ & Social obligation & Shared meanings \\
\hline Basis of order & Regulative rules & Expectations & Constitutive scheme \\
\hline Mechanism & Coercion & Normative & Mimetic \\
\hline Indicators & $\begin{array}{c}\text { Laws, rules, } \\
\text { sanctions }\end{array}$ & $\begin{array}{c}\text { Certification, } \\
\text { professional license }\end{array}$ & $\begin{array}{c}\text { Shared beliefs, logic of } \\
\text { action }\end{array}$ \\
\hline $\begin{array}{l}\text { Basis of } \\
\text { legitimacy }\end{array}$ & $\begin{array}{c}\text { Legally } \\
\text { sanctioned }\end{array}$ & Morally guided & $\begin{array}{c}\text { Culturally supported, } \\
\text { recognizable }\end{array}$ \\
\hline
\end{tabular}

Source: Adapted according to Scott R. W. (2001), Institutions and Organizations, Thousands Oaks, CA: Sage.

Regulative institutions rely on normative rules which have prescriptive, evaluative and obligatory dimension - they prescribe actions, evaluate actions and create an obligation of behaving in a certain way. Examples of regulative institutions are laws enacted by the Parliament or rules enacted by the Government, which largely prescribe structuring and functioning of organizations in different sectors and ensure their application by means of sanction threats, i.e. by the use of force.

Normative institutions are based on professional standards, values and behavior norms. Professions are institutions in itself, which prescribe not only what is a legitimate goal of activities and what should be done, but also the means of achieving the goal, that is, how to achieve it. Specific norms of how to perform a certain function are actually roles. Beliefs on how the role should be performed are actually a prescriptive rule which, as it is socially expected, applies pressure and must be fulfilled. Norms not only determine the way of behavior, but also the rights, obligations and privileges.

Cultural-cognitive institutions are mutual beliefs and concepts defining social reality and determining its meaning. In this meaning, the institution is a kind of crystallization or sedimentation (layer) of meaning. The starting points are social construction of reality and significance that cognitive structures have for one and the assumption that one acts in accordance with one's own representations of reality. This type of institution implies mutual meanings (cultural dimension) and the fact that they are part of interpretative schemes of individuals (cognitive dimension). These institutions ensure that a certain kind of behavior is experienced not as imposed by professional rules (normative institutions) and laws (regulative institutions), but as the only proper and possible behavior. 
Legitimacy of action of an organization is determined by all three institutions, but each in its own way: regulative institutions monitor if the laws and rules are followed; normative institutions evaluate if the behavior is in compliance with the expectations that the professional norms (written and unwritten) prescribe, and cultural-cognitive institutions give legitimacy only to those actions which are in compliance with socially constructed image of reality and values and beliefs that emerge from that image.

\section{Coercive, Normative and Mimetic Mechanisms of Institutional Impact on Organizations}

Institutions determine the behavior of organizations within a sector in three different ways and through three different processes: coercive, normative, and mimetic (Pedersen, Dobbin, 2006). Coercive process implies that structures, processes, and meaning are coerced by explicit or implicit laws, either formal or informal. Mimetic process implies that, when dealing with unknown, unclear, and uncertain events in the environment and when the relation between conduct and consequences is unfamiliar, an organization imitates (mimics) other organizations in the sector, which it believes to know better in order to decrease the risk of acting in such uncertain situations. Normative process implies professionalization, that is, organizations must accept some structures, processes and beliefs imposed by a certain profession. Professional standards are imposed through education and through professional associations which have a strong motif of keeping the standards (e.g. accounting associations).

If any institution has any kind of impact, the consequence of that impact on organizations within the sector is organizational isomorphism. When this occurs, the organizations within a sector start to resemble each other more and more in both their structure and the way of functioning. It is logical that, if all organizations must follow and implement the same institutionalized rules of operating, then in the course of time all of them become alike - isomorphous. The more the society as a whole is institutionalized, and the more and the longer a sector is exposed to institutionalization, the organizations within it will be more alike. It is noticeable that, for example, all informative programs reporting the news on all televisions in the world are alike and that they, in fact, use one pattern and format, which was long ago created by the CNN.

Since there are three mechanisms of institutional impact on organizations, there are three types of isomorphism (DiMaggio, Powell, 1983). Coercive isomorphism arises as the consequence of formal and informal pressures that the organizations in the sector are exposed to by the state, profession, other organizations on which it depends (e.g. all car parts suppliers of a major car producing company must implement specific systems and procedures), as well as the pressures present in the form of cultural expectations. Pressures may be 
direct, as is most often the case with requests set by the state authorities, but they may also much more subtle, as is the case with pressures in the form of cultural expectations or profession.

Mimetic isomorphism arises as the consequence of inability of organizations to independently solve problems they encounter. Organizations look up to other organizations as their models. Firms apply structures which they copy from successful companies believing that it would ensure them success and disregarding the differences of the context in which those structures are implemented. Mimicking is also done through consulting practice, since consultants use one organization as a model whose experiences they transfer into other organizations. Quality management implementation in U.S. companies is the consequence of mimicking the Japanese practice.

Normative isomorphism emerges from professionalization. Professionalization is a collective effort of members of one profession to set rules and limitations which will regulate working methods in the profession and to establish a cognitive foundation to their autonomy (Ashworth et al., 2007).

\section{Reactions of Organizations on Imposing an Institutional Pattern}

It is intriguing that so far, the institutional theory has not dealt much with the issue of the reaction of organizations to an imposed institutional pattern (Scott, 2001; Edelman, 1992; Oliver, 1991). The institutional theory has offered explanations of the nature, the way of creation, and the way of imposing of the structure and processes' patterns on organizations, but it has not offered much in the explanation of organizations' reactions to these patterns. Still, there are some notable exceptions, starting from Meyer and Rowan's (1977) concept of decoupling, through the works of Oliver (1991, 1992), Edelman (1992), Greenwood and Hinings (1996), and Casile and Davis-Blake (2002), to the work of Pedersen and Dobbin (2006).

The review of literature shows that organizations faced with the pressure to apply the institutional pattern of structure and functioning can react in several ways. First, they can obey the institutional environment requirements and completely accept and implement the institutionalized rules of structuring and functioning. This kind of organization's reaction is primarily expected and it is in accordance with the institutional theory postulates (Ashworth et al., 2007). Second, organizations can adapt the institutional pattern to their own needs and resources, values or interests, and implement thus adjusted pattern. This type of organizations' reaction was named hybridization by Pedersen and Dobbin (2006), while Oliver (1991) called it compromise. Third, organizations can pretend to implement the institutional pattern, while in reality they are actually not implementing it. This fiction is achieved through symbols, such as rituals, language phrases or material symbols. Meyers and Rowan (1977), as well as 
Edelman (1992) have described this process, while Oliver (1991) called it avoidance and Pedersen and Dobbin (2006) named it transmutation. Forth, in certain circumstances, organizations can even, openly or covertly and more or less aggressively, refuse to implement the institutional pattern. The consequence of this refusal is inertness of the organization (Hinings, Greenwood, 1988). Casile and Davis-Blake (2002) have also described this scenario, while Pedersen and Dobbin (2006) named it immunization. Oliver (1991) has even distinguished two types of refusal: the one accompanied by attempts to impact institutions and the one without these attempts.

\section{Organization of the Higher Education Sector through the Lens of the Organizational, Institutional Theory}

Organization of the higher education sector, as well as of universities and their pertaining faculties, in European, as well as in Serbian, educational area can best be understood through the application of the institutional organizational theory. Educational system structure, as well as the structure and functioning of universities and faculties, is an excellent example of how application of institutional organizational theory arguments can help understanding of modern organizations. In the remaining part of this paper, we will show that all the relevant phenomena described in the institutional, organizational theory can be found in the higher education sector.

Organizational isomorphism, pointed out as a symptom of sector institutionalization at the beginning of this paper, is highly present in higher education in both Europe and Serbia. This isomorphism is noticeable not only at the level of higher education organizations, that is, universities and faculties, but also at the level of the entire system of education. Thus, for example, all higher education systems in Europe have a structure of a three-cycle degree system and they consist of undergraduate (Bachelor degree), graduate (Master degree) and doctoral studies (PhD degree). In almost all higher education systems in Europe, undergraduate studies take three years, graduate studies for a Master's degree take two years and doctoral studies for a $\mathrm{PhD}$ degree take three years, although there are variations with undergraduate studies taking four years and graduate studies for a Master's degree one year. In all higher education systems, workload of students is measured in the same way and expressed through a unique European Credit Transfer and System (ECTS). In all higher education systems there is a mandatory degree paper and diploma supplement. In addition, in all the systems, one way or another, accreditation of universities and faculties is conducted by applying similar standards. Also, in all European countries, organization and functioning process of universities and faculties are similar: in all faculties, classes are held through interactive forms and high degree of student participation, students' work is evaluated in different ways during classes, teaching process quality assurance system has the same elements 
at all universities and faculties (student survey, self-evaluation), and work transparency of all universities and faculties is ensured in the similar way. Teacher promotion is conducted based on a combined score of their scientific research results and publications and their teaching accomplishments.

A highly prominent isomorphism of the European higher education system, as well as of the universities and faculties within it, is due to implementation of one institutional pattern of higher education structuring and functioning, the socalled "Bologna Model” (European University Association, 2014). This model was created, institutionalized, and as such imposed on all higher education systems, as well as universities and faculties, in European higher education area. The Bologna higher education model emerged as a result of the so-called "Bologna Process" , a long-term political project of creating a uniform higher education system in the European Union. This project started with a Declaration signed in Bologna in 1999 by European Ministers of Education (The Bologna Declaration, 1999). Until this day, in all the European Union countries, as well as in those striving to become EU members, the process of institutionalization and implementation of the Bologna higher education model is an ongoing, more or less successful, process. The European Ministers of Education even periodically evaluate (on a scale of 1 to 5 , just like in school) education systems in individual countries in the sense of how far did they go in the implementation of the Bologna higher education model. Although it is not yet a member of the EU, Serbia is also putting in effort to implement the higher education model created in Bologna. With a slight modification, which enables undergraduate studies to last for three to four years and postgraduate studies for a Master degree to last one or two years, the higher education system in Serbia has all the listed higher education elements that other countries in the European higher education area have.

The consequence of the Bologna higher education model institutionalization is that European higher education systems, as well as the universities and faculties within it, now do not prove their legitimacy as a social resource users by their rationality, efficiency, or their performance, but by mere implementation of the elements prescribed by the Bologna Model. The educational system of a country, as well as of the universities within it, is not evaluated by the level of knowledge it provides to students, the average length of studies, the number of students that enroll and graduate from its faculties, or the number of scientific works published by its teaching staff, but by the degree in which the Bologna higher education model is implemented in the educational system or at a university within it.

In all countries, the higher education sector is a typical example of a highly institutionalized sector. This sector is an excellent candidate for institutionalization, since it meets both requirements for a sector to be institutionalized. First of all, it is very difficult to measure and standardize the 
quality of higher education outputs. Thus, it is almost impossible to measure the successfulness of a university by applying technical criteria of rationality and economic efficiency. We have no choice but to judge the quality of a university or faculty based only on the extent in which it meets the standards of the currently accepted institutional pattern. Also, the higher education sector cannot significantly control its own resources inputs and flows. This is especially true for state universities, which makes them more intensively exposed to the process of institutionalization. Finally, every country and its political elite strive to put the higher education sector under their control, and the best way to do just that is through its institutionalization. Let us not forget that the Bologna higher education model was not created by the academic community, but by administrations of the European Union countries' Ministries of Education.

As an institutional pattern, the Bologna higher education model has elements of all three types of institutions: regulative, normative, and culturalcognitive. Cultural-cognitive features of this pattern are recognized in mutual values and beliefs that make its basis from which operative solutions emerge in the pattern (European University Association, 2014). Namely, the Bologna Process is based on the belief about the necessity of creating a uniform European educational area in which all the students and higher education teachers will be able to freely move and in which the degree acquired in one country will be valid in any other European country. In this way, mobility of the workforce would be provided in the European economy. Out of this particular belief, an important element of the Bologna Model emerges - the European Credit Transfer and System (ECTS). ECTS evaluates workload of students and expresses it in the number of hours needed to cope with the assigned studying material. The Bologna Model requires that all universities and faculties express their studying programs through an ECTS number, whereby it creates a realistic foundation for a student to start the studies at one university in one country, and finish it at another university in another country. Also, in this way, an employer in any state, when hiring, would be sure that a graduate has a certain level of knowledge no matter which country the graduate comes from. The other important belief, as a cultural-cognitive element of the Bologna Model, is the belief in the need to adapt the education to the users' needs, that is, to the needs of the economy and society. The history of European higher education is the history of tensions between the universities, that have closely guarded their autonomy and the right to decide for themselves what they will teach the students and how, and the state, that has tried to ensure that students receive as much as possible of the practical knowledge essential to their future employers. It seems that the Bologna Process is the state's final victory in this centurieslong struggle because it implies several important higher education system characteristics aimed precisely at this practicality and economic effectiveness of educations. Namely, the Bologna Process introduces the three-stage education where undergraduate studies last for three years. In this way, students can faster 
acquire their first diploma, so the higher education is therefore less costly for the state. Also, undergraduate studies have a practical orientation in order for the students to gain only those competencies that are necessary for particular jobs. Finally, the interactive teaching process, practice, and evaluation of knowledge during the entire teaching process, which the Bologna Model introduces, also lead to a faster completion of studies and gaining more practical and operative knowledge.

Besides cultural-cognitive characteristics, the Bologna higher education model also has characteristics of a regulative institution. They are primarily noticeable in the fact that the Bologna Model was created by a document signed by all the Ministers of Education of all the EU countries at that moment (The Bologna Declaration, 1999). Thus, implementation of this institutional model has become mandatory for all the signatory countries, that is, for all the EU member states, as well as for those countries that intend to become part of the EU. The Bologna higher education model is transferred into higher education laws enacted separately by all the EU member states, current and future ones, and these laws as such have become regulatory instruments in higher education organizing and functioning. Serbia has done that by enacting the Higher Education Law in 2005 (Parliament of Serbia, 2005). By enactment of this Law, the basic elements of the Bologna higher education model have been imposed on all the universities and faculties in the country. In addition, the National Higher Education Council and the Commission for Accreditation and Quality Assurance have been formed by means of this Law. These bodies have created and, through the process of higher education institutions' and study programs' accreditation process, ensured implementation of quality standards in higher education in Serbia. Quality standards, based on which accreditation was conducted, have the strength of law in Serbia; hence, they are another regulatory element of the Bologna institutional pattern (Commission for Accreditation and Quality Assurance, 2006).

The Bologna Model also has elements and characteristics of a normative institution. Its implementation is ensured not just by means the Law, but also by means of higher education professional standards shared by the academic community in the European educational area. Some solutions of the Bologna higher education model are not regulated by law, but they have become a professional standard that the universities and their teaching staff, lead by desire to receive legitimacy in the European educational area, apply even when they do not completely believe in them. A university teacher in the European educational area cannot nowadays be a legitimate member of the academic community unless, at least verbally, he or she does not support and implement the basic elements of the Bologna higher education model, regardless of what he or she may personally think of it. Interactive classes cannot be prescribed by law, but it has become a professional standard of teaching in the European educational area. 
The Bologna higher education institutional pattern was imposed coercively, normatively, as well as mimetically. Coercive implementation of the Bologna Model is ensured through building the basic elements of the Bologna process into higher education laws in all the signatory countries of the Bologna Declaration, as well as through enforcement of these laws. This was also the case in Serbia, since the Higher Education Law specifies the implementation of basic elements of the Bologna Model (Parliament of Serbia, 2005). The other mechanism of coercive implementation of the Bologna higher education model elements is the process of accreditation. Since the higher education institutions in Serbia cannot be operative unless they are accredited, it actually means that the Bologna Model elements contained in the accreditation standards are actually coercively imposed on universities and faculties (Comission for Accreditation and Quality Assurance, 2006). The normative mechanism of the Bologna institutional pattern implementation is visible through the impact of the Bologna process as a professional model of good practice and desirable way of university teachers and researchers' behavior. Normative impact is also spread through inter-university cooperation, professional associations, as well as through scientific conferences. The European Association for Quality Assurance in Higher Education (ENQA) also represents a normative mechanism of the Bologna Model impact. This important institution prescribes the accreditation content and process in higher education sphere (Comission for Acreditation and Quality Assurance, 2006). ENQA membership is not mandatory, but it does contribute to the level of acknowledgement and prestige. Thus, in order to become the ENQA member, the Serbian Commission for Accreditation and Quality Assurance (CAQA) had to meet a number of normative requirements regarding accreditation standards and the very process of accreditation. Finally, the mimetic process of the Bologna Model implementation is more than visible. Many universities and faculties in Serbia, and especially those newer ones (mostly privately owned ones), have downloaded the study programs curricula from the Internet, that is, they have copied them from the world-famous universities. Study surveys, textbook quality assurance standards and many other elements of the Bologna Model have spread out mimetically throughout the faculties in Serbia. It is interesting that the mimetic process was built into the very accreditation standards in Serbia. Namely, one of the study program accreditation standards required a faculty to prove the similarity of the study program it wishes to accredit with at least three already accredited study programs. Thus, the faculties were by means of accreditation standards, more or less, forced to mimetically implement the Bologna Model. The consequence of the coercive, normative and mimetic imposition of the Bologna higher education model is the above described organizational isomorphism of universities and faculties.

The type of reactions of Serbian universities and faculties to imposing of the Bologna higher education institutional pattern are all those already described in 
the literature. The universities in Serbia have fully implemented, modified and implemented, symbolically implemented, but also rejected to implement the elements of the Bologna higher education model supported by the law and the accreditation standards. Example of a full implementation of the Bologna Model is found in the acceptance of a three-cycle degree higher education structure, and also in one entirely new higher education feature in Serbia - $\mathrm{PhD}$ studies. They did not exist in higher education in Serbia before the Bologna Model implementation; before that, candidates for a $\mathrm{PhD}$ degree obtained the PhD diploma solely by writing the doctoral dissertation. By accepting the Bologna process, the obligation of organizing $\mathrm{PhD}$ studies in the duration of three years was prescribed first by the Higher Education Law and afterwards also by the Accreditation Standards, in order for the universities and faculties to fully accept and implement these regulatory institutional requirements. This is the reason why today all the universities and their pertaining faculties in Serbia have classes as part of $\mathrm{PhD}$ study programs, and the very $\mathrm{PhD}$ studies are organized in the way which is set as standard in the entire Europe.

Some elements of the Bologna higher education pattern were first modified and adjusted in order to be implemented by the universities in Serbia. A typical example of such university reaction is the implementation of $\mathrm{PhD}$ teachers and mentors' competency accreditation standard (Commission for Accreditation and Quality Assurance 2006). Faced with the fact that the set teacher competency accreditation standard cannot be met by the teachers of social-humanistic science faculties, The University of Belgrade has just loosened this standard and then implemented it in such a loosened form.

Some elements of the higher education institutional pattern have only symbolically been implemented by Serbian faculties and universities. The quality assurance system has been imposed on Serbian faculties and universities by the Bologna higher education model, and they have started to implement it. But, many elements of the said system were implemented only symbolically in order to show that the Bologna process was accepted, but without their essential implementation and with no real effects. Thus, faculties have indeed been conducting selfevaluation processes and student surveys on classes' quality, but only as a ritual showing that they have been implementing the Bologna higher education model, since these activities have not had any real effects nor have been intended to have any effects. Also, as a very important prerequisite for interactive classes, the class size was also prescribed by the accreditation standards (Commission for Accreditation and Quality Assurance 2006). But, in most cases, the faculties have only on paper shown that the student groups contained the prescribed number of students, while in practice this number has always been far greater.

Finally, Serbian universities and faculties have, more or less concealingly, rejected to implement some of the higher education institutional pattern requirements. Thus, some faculties have enrolled more than the prescribed 
number of newly enrolled students set in the accreditation standards, and they have held classes at the departments they were not accredited for.

\section{Conclusion}

The institutional theory of organization is a relatively new theoretical perspective that enables understanding of some processes and phenomena in structuring and functioning of modern organizations that the traditional theory of organization cannot explain. The reason for this is the institutionalization process in the ever larger number of sectors of modern societies. This process implies that actors in one sector of economy or society, through the process of constructing social reality, create the pattern of structuring and functioning of all organizations in the sector, and then make it legitimate by pronouncing it the only one valid, appropriate, and desirable model of behavior of all the actors within the entire sector, and then finally impose it on the said actors. Organizations within the sector must accept the institutional pattern of structuring and functioning in order to prove their legitimacy as a user of social resources. Due to a subjective character of the institutionalization process, institutional pattern does not have to be, and it is often not, lead by the criteria of technical rationality and economic efficiency. The institutional pattern of structuring and functioning in one sector has its regulative, normative and cultural-cognitive dimension. It is imposed on organizations within the sector through coercive, normative and mimetic mechanisms. As the consequence of implementation of the same structuring and functioning pattern in one sector, the organizations within it become isomorphous.

In modern societies, more and more sectors are being institutionalized due to both ever harder evaluations of organizational performance, and more prominent striving of social and political elite to control the actors in the said sector through institutionalized behavior patterns. The higher education sector is one of the typical highly institutionalized sectors; hence, organization and functioning of the units, universities and faculties, within that sector cannot be understood by using the traditional theories of organization, but solely through the prism of the institutional organizational theory. In the higher education sector in Europe, as well as in Serbia, the structuring and functioning of the entire higher education system, as well as of the universities and faculties within the system, is contained in the Bologna Higher Education Model which has all the characteristics of an institutionalized pattern of structuring and functioning. It was created outside of universities and faculties, institutionalized, and imposed on all the universities and faculties within the European educational area. This pattern has regulatory, normative, and cultural-cognitive dimensions and it has been imposed through coercion, normative, and mimetic mechanisms. The consequence of this is an organizational isomorphism of universities and faculties in the European higher education area, and thereby in Serbia as well. 


\section{References}

Ashworth, R., G. Boyne, and R. Delbridge (2007) "Escape from the iron cage? Organizational change and isomorphic pressures in the public sector", Journal of Public Administration Research and Theory, 19:165-187.

Berger, P. and T. Luckmann (1967) The social construction of reality: A treatise on the sociology of knowledge, New York, NY: Doubleday.

Casile, M. and A. Davis-Blake (2002) "When accreditation standards change: factors affecting differential responsiveness of public and private organizations”, Academy of Management Journal, 45 (1): 180-195.

DiMaggio, P. J. and W. W. Powell (1983) "The iron cage revisited: institutional isomorphism and collective rationality in organizational fields”, American Sociological Review, 48 (2):147-160.

Edelman, L. B. (1992) "Legal ambiguity and symbolic structures: Organization mediation of civil rights law”, The American Journal of Sociology, 97 (6):1531-1576.

Frumkin, P. and J.Galaskiewicz (2004) "Institutional isomorphism and public sector organizations”, Journal of Public Administration Research and Theory, 14(3): 283-307.

Greenwood, R. and C. R. Hinings (1996) "Understanding Radical Organizational Change: Bringing Together The Old and The New Institutionalism”, Academy of Management Review, 21 (49):1022-1054.

Hinings, C. and R. Greenwood (1988) The dynamics of strategic change, London: Basil Blackwell.

Hinings, C. R., R. Greenwood, T. Reay, and R. Suddaby (2004) "Dynamics of change in organizational fields”, in M. S. Poole, and A. Van de Ven (Eds.), Handbook of organizational change and innovation, Oxford: Oxford University Press, pp. 126- 140.

Hinings, C. R. and P. S. Tolbert, (2008) "Organizational institutionalism and sociology: a reflection”, in Greenwood, R., C. Oliver, K. Sahlin, and R. Suddaby (eds.), The Sage handbook of organizational institutionalism, Thousand Oaks, CA: Sage Publications, pp. 473-490.

Jepperson, R. (1991) "Institutions, institutional effects and institutionalism”, in Powel, W. and P. DiMaggio (eds.), The Institutionalism in Organizational Analysis, Chicago: The University of Chicago Press, pp. $143-164$.

Jones, G. (2001) Organizational Theory, Upper Sadle River, NJ: Prentice Hall.

Kostova, T. (1999) "Transnational transfer of strategic organizational practices: a contextual perspective”, Academy of Management Review, 24 (2): 308-324.

Meyer, J.W. and B. Rowan (1977) "Institutionalized organizations: Formal structure as myth and ceremony”, The American Journal of Sociology, 83 (2): 340-363.

Mintzberg, H. (1979) The structuring of organizations, Englewood Cliffs, CA: Prentice Hall.

Oliver, C. ( 1991) "Strategic responses to institutional processes”, Academy of Management, $16(1): 145-179$.

Oliver, C. (1992) “The antecedents of deinstitutionalization”, Organization Studies, 13 (4): 563-588.

Pedersen, J. S. and F. Dobbin (1997) “The Social invention of collective actors", The American Behavioural Scientist, 40 (2): 431-443. 
Pedersen, J. S. and F. Dobbin (2006) "In search of identity and legitimation: bridging organizational culture and neoinstitutionalism”, American Behavioral Scientist, 49(7): 897-907.

Scott, R.W. (1987) “The adolescence of institutional theory”, Administrative Science Quarterly, 32 (4): 493-511.

Scott, R.W. (1991) “Unpacking institutional arguments”, in Powell W. W. and P. J. DiMaggio (eds.) The new institutionalism in organizational analysis, Chicago, IL: The University of Chicago Press, pp.164-183.

Scott, R.W. (2001) Institutions and organizations, $2^{\text {nd }}$ ed., Thousands Oaks: Sage

Thornton, P. H. (2002) "The rise of the corporation in a craft industry: conflict and conformity in institutional logics”, Academy of Management Journal, 45: 81-101.

Zucker, L. G. (1977) “The role of institutionalization in cultural persistence”, American Sociological Review, 42:726-743.

Comission for Acreditation and Quality Assurance (2006) Rules and regulations on accreditation standards and procedures of higher education institutions and study programs. http//www.kapk.org. Accessed 1. April, 2014.

European University Association (2014), What is Bologna Process?, http://www.eua.be/euawork-and-policy-area/building-the-european-higher-education-area/bolognabasics.aspx, Accessed, 10. April 2014.

Parliament of Serbia (2005) Higher Education Act. http//www.parlament.gov.rs. Accessed 1. April 2014.

The Bologna Declaration (1999), http://www.eua.be/eua/jsp/en/upload/OFFDOC _BP_bologna_declaration.1068714825768.pdf, Accessed, 10 April 2014

\section{INSTITUCIONALNA ORGANIZACIONA TEORIJA KAO NOVI ISTRAŽIVAČKI OKVIR ZA RAZUMEVANJE SAVREMENIH ORGANIZACIJA}

Apstrakt: U radu se prezentiraju osnovni postulati institucionalne organizacione teorije kao novog istraživačkog okvira za razumevanje strukturiranja i funkcionisanja savremenih organizacija. Sve veći broj sektora u savremenim društvima postaje institucionalizovan usled promena u tehničko tehnološkoj, društvenoj i političkoj sferi. Svoju legitimnost organizaicje u institucionalizovanim sektorima ne dokazuju racionalnošću i efikasnošću, već primenom važećeg institucionalnog obrasca. Institucionalni obrazac ima svoju regulativnu, normativnu i kulturno kognitivnu komponentu a organizacijama u sektoru nameće se kroz prinudni, normativni i mimetički mehanizam. Posledica primene jedinstvenog institucionalnog obrasca $u$ struturiranju $i$ funkcionisanju svih organizacija $u$ sektoru jeste organizacioni izomorfizam. Opisani elementi institucionalne organizacione teorije su primenjeni $u$ analizi strukturiranja i funkcionisanja univerziteta i fakulteta u sektoru visokog obrazovanja u Evropi i Srbiji. Pokazano je kako Bolonjski model visokog obrazovanja, kao tipičan institucionalni obrazac, utiče na strukturiranje i funkcionisanje svih univerziteta $\mathrm{i}$ fakulteta $\mathrm{u}$ evropskom obrazovnom prostoru, implicirajući time njihov organizacioni izomorfizam.

Ključne reči: institucija, teorija, organizacija, visoko obrazovanje, univerzitet 